\title{
PHYLOGENETIC AND ECOLOGICAL SIGNALS IN THE WOOD OF SPATHELIOIDEAE (RUTACEAE)
}

\author{
Marc S. Appelhans ${ }^{1,2}$, Bertie Joan van Heuven ${ }^{1}$, Frederic Lens ${ }^{1}$ and \\ Pieter Baas $^{1}$
}

\section{SUMMARY}

\begin{abstract}
Subfamily Spathelioideae of Rutaceae constitutes a well-supported early branching clade of eight small woody genera that were formerly assigned to five different Sapindalean/Rutalean families. This study brings together detailed wood anatomical information on all eight genera (for four the wood anatomy is described for the first time in detail). Wood anatomy strongly supports the inclusion of all Spathelioid genera in Rutaceae and underpins the molecular phylogeny with a set of interesting apomorphies at different nodes of the cladogram. The wood anatomy of Cneorum tricoccon with its semi-ring porosity, dendritic vessel pattern, vascular tracheids and helical vessel wall thickenings stands out in Spathelioideae. This wood anatomical syndrome is hypothesized to be due to adaptive evolution for hydraulic safety and efficiency of this species in a typical Mediterranean climate, where similar syndromes have evolved in many unrelated clades of woody dicots. In at least six unrelated genera of Rutaceae outside Spathelioideae from Mediterranean or cool temperate and montane climates, the syndrome has also evolved in presumably parallel, adaptive evolution.
\end{abstract}

Key words: Cneorum, Dictyoloma, Harrisonia, Sohnreyia, Spathelia, vessel grouping, hydraulic safety, prismatic crystals, xylem rays.

\section{INTRODUCTION}

Spathelioideae (= Cneoroideae sensu Kubitzki et al . 2011) are a clade of about 30 species in eight genera that form the sister group to Rutaceae sensu stricto, and the clade is currently regarded as a subfamily of Rutaceae sensu lato (Chase et al.1999; Groppo et al.2008; Razafimandimbison et al.2010; Appelhans et al.2011). Prior to molecular phylogenetic analyses, these eight genera had not been regarded as close relatives due to their strikingly different morphology (see Appelhans et al. 2011), and they have been included in various Sapindalean/Rutalean families: Cneoraceae (Cneorum L.; Straka et al. 1976), Meliaceae (Cedrelopsis Baill., Ptaeroxylon Eckl. \& Zeyh.; Engler 1931; White 1986), Ptaeroxylaceae (Bottegoa Chiov., Cedrelopsis, Ptaeroxylon;

1) Naturalis Biodiversity Center, National Herbarium of the Netherlands, P.O. Box 9514, 2300 RA Leiden, The Netherlands.

2) Department of Botany, National Museum of Natural History, Smithsonian Institution, P.O. Box 37012, MRC 166, Washington, DC 20013-7012, U.S.A. [E-mail: appelhansm@si.edu]. 
Leroy 1959, 1960; Van der Ham et al. 1995), Sapindaceae (Bottegoa; Chiovenda 1916), and Simaroubaceae (Dictyoloma A.Juss., Harrisonia R.Br. ex A.Juss., Sohnreyia K. Krause, Spathelia L.; Planchon 1846; Bentham \& Hooker 1862; Nooteboom 1962). Only Dictyoloma, Sohnreyia and Spathelia have been included in Rutaceae by most authors (e.g. Engler 1931; Thorne 1992; Takhtajan 1997), as they clearly exhibit secretory cavities in the leaves, which constitute one of the most common and taxonomically important features of the family (Engler 1931; Kubitzki et al.2011).

Spathelioideae have a pantropical distribution, which extends to subtropical regions in the Mediterranean and the Canary Islands (Cneorum). Spathelioideae contain a Neotropical subclade (Dictyoloma, Sohnreyia, Spathelia), which is sister to the Palaeotropical subclade (Bottegoa, Cedrelopsis, Cneorum, Harrisonia, Ptaeroxylon). A detailed distribution map is provided by Appelhans et al. (2012).

All species within Spathelioideae are woody. However, their habits differ considerably from small shrubs (usually about $1 \mathrm{~m}$ in height) in Cneorum, to scandent shrubs and climbers in Harrisonia, and small to medium-sized (seldom large) trees in the African and Malagasy genera Bottegoa, Cedrelopsis and Ptaeroxylon. The two Neotropical genera, Sohnreyia and Spathelia, usually do not branch at all (Appelhans et al.2011; Kubitzki et al. 2011). Occasionally, Sohnreyia and Spathelia plants can have two or three branches and the first author has observed two-branched specimens of Spathelia glabrescens, which were obviously caused by injury or decapitation of the main stem.

Except for Cneorum, all Spathelioideae taxa are distributed in tropical regions. A few species are known only from their type locality or several localities and their ecology has not been studied. Most taxa, however, occur in semi-dry and seasonal conditions (Appelhans et al. 2012, supporting information S2). One species of Cneorum is distributed in the Canarian dry coastal succulent bush (C.pulverulentum) and the other in Maquis shrubland in the western Mediterranean (C.tricoccon) (Bramwell \& Bramwell 1990; Traveset 1995). Both species occur under distinctly arid conditions, although the seasonal temperature changes in the Western Mediterranean are considerably higher than those in the Canary Islands (Juan et al. 2000).

Several wood anatomical descriptions of Spathelioideae are available (Metcalfe \& Chalk 1950; Détienne \& Jacquet 1983; Carlquist 1988; Schweingruber 1990; Ilic 1991; Van der Ham et al. 1995; InsideWood 2004-onwards; Mollel et al. 2008; Appelhans et al. 2010), but detailed anatomical descriptions are lacking for four genera. Van der Ham et al. (1995) studied several morphological and anatomical characters of Bottegoa in comparison to Cedrelopsis, Harrisonia and Ptaeroxylon and showed the taxonomic importance of wood anatomical characters in this group.

The goals of this study are: 1) to accomplish the first comparative wood anatomical study including all Spathelioideae genera, 2) to evaluate if there are common wood anatomical characters for Spathelioideae, which might be considered as synapomorphies for this heterogeneous group, and 3) to find out if the wood anatomy of the Mediterranean and Canarian genus Cneorum differs considerably from the tropical members of Spathelioideae. 


\section{MATERIALS AND METHODS}

Vouchered wood samples of Dictyoloma, Harrisonia, Sohnreyia, and Spathelia, present in the wood collections at Leiden (Lw \& Uw, cf. Index Xylariorum 4, http://www. kew.org/collections/wood-index/Index_Xylariorum4.htm) or cultivated in the Hortus botanicus in Leiden were softened in boiling water, sectioned and stained using standard methods (cf. Baas et al. 1988). In addition macerations were prepared using Franklin's method (incubation in hydrogen peroxide and glacial acetic acid) and stained with Astrablue. Qualitative and quantitative wood anatomical features were recorded following recommendations of the IAWA Hardwood List (Wheeler et al. 1989). Data on the wood anatomy of the remaining genera of Spathelioideae, Bottegoa, Cedrelopsis, Cneorum, Ptaeroxylon, were gleaned from the literature and coded descriptions on the InsideWood web-database (InsideWood 2004-onwards; Wheeler 2011), and verified with slides from the reference slide collections in Leiden (Lw \& Uw).

\section{RESULTS}

\section{Wood anatomical descriptions}

Detailed wood anatomical descriptions are given here for the four Spathelioideae genera for which no detailed accounts are available in the literature. For a summary of the wood anatomy of Bottegoa (based on Van der Ham et al. 1995), Cedrelopsis (based on Mollel et al. 2008, and InsideWood 2004-onwards), and Ptaeroxylon (based on Metcalfe \& Chalk 1950; Van der Ham et al. 1995 and literature cited there, and Inside Wood 2004-onwards) see Table 1, which also summarizes the four generic descriptions below and information on Cneorum based on Carlquist (1988) and Schweingruber (1990).

Table 1. Some diagnostic wood anatomical characters of genera of Spathelioideae.

Vessel pattern $:-=$ no special pattern; $\mathrm{de}=$ dendritic; $\mathrm{di}=$ diagonal; $\mathrm{ra}=$ radial; ()$=$ pattern weakly developed. - Ray composition: sq.up.proc: square and upright cells abundant in addition to procumbent cells; proc: most ray cells procumbent; sq. up: most ray cells square and upright. - Crystals: $-=$ absent; $\mathrm{cc}=$ chambered crystals in axial elements; $\mathrm{rc}=$ crystals in ray cells; $(\mathrm{l})=$ crystal type very rare .

\begin{tabular}{lcccc}
\hline & Vessel pattern & Ray width & Ray composition & Crystals \\
\hline Bottegoa & - & 1 & sq.up.proc & $\mathrm{cc}$ \\
Cedrelopis & - & 1 & proc & $\mathrm{cc}$ \\
Ptaeroxylon & $\mathrm{ra}$ & 1 & proc & $\mathrm{cc}$ \\
Cneorum tricoccon & $\mathrm{de}$ & 1 or $1-3(4)$ & sq.up.proc & $\mathrm{cc}+\mathrm{rc} \mathrm{or}-$ \\
Cneorum pulverulentum & $\mathrm{ra}$ & $1(-2)$ & proc & $\mathrm{cc}$ \\
Harrisonia & $-(\mathrm{ra}, \mathrm{di})$ & 1 or $1-3$ & sq.up & $\mathrm{rc}(\mathrm{cc})$ \\
Dictyoloma & - & $1-2(3)$ & proc & - \\
Sohnreyia & $\mathrm{ra} \mathrm{(di)}$ & $1-3$ & proc & - \\
Spathelia & $(\mathrm{ra}, \mathrm{di})$ & $1-4(5)$ & proc & - \\
\hline
\end{tabular}



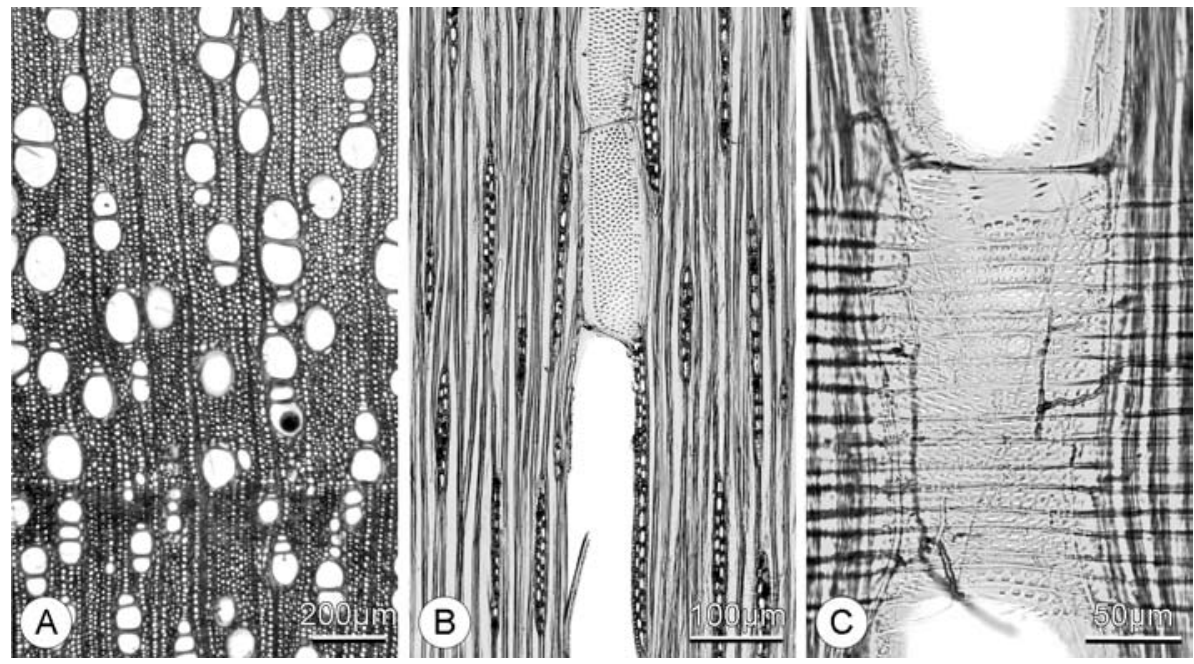

Figure 1. Wood anatomy of Dictyoloma vandellianum (Uw 17616). - A: Cross section showing vessel element in radial multiples and wide, narrow vessels, faint growth ring visible. - B: Tangential section with uniseriate and biseriate rays. $-\mathrm{C}$ : Radial section showing procumbent ray cells.

\section{Dictyoloma (Fig. 1)}

Material studied: D. vandellianum A.Juss (Syn: D. peruvianum, D. incanescens). Peru, Uw 17616 (= Dutton et al.3967; thick branch or thin trunk).

Growth ring boundaries varying from faint to fairly distinct, and in the latter case marked by differences in fibre wall thickness and/or discontinuous marginal parenchyma. Vessels diffuse, some solitary, but mainly in radial multiples of 2-6 (multiples of 4 or more not uncommon); $32(20-41) / \mathrm{mm}^{2}$, round to oval, tangential diameter $86(17-113) \mu \mathrm{m}$, often with wide and narrow vessels in the same multiple, vessel elements 380 (315-480) $\mu \mathrm{m}$ long. Perforations simple. Intervessel pits alternate and small, 5-7 $\mu \mathrm{m}$ in horizontal diameter. Vessel-ray and vessel-parenchyma pits similar. Gums and tyloses absent from the vessels.

Fibres medium thick-walled, 821 (513-1120) $\mu \mathrm{m}$ long, nonseptate, with simple to minutely bordered pits mainly confined to the radial walls.

Parenchyma scarce, scanty paratracheal and in poorly defined discontinuous marginal (initial) bands of varying width, in 3-7-celled strands.

Rays 8 (6-12)/mm, 1-2(-3)-seriate, mostly homocellular and composed of procumbent cells only, but some with one marginal row of square to weakly upright cells, tallest rays up to 22 cells or $900 \mu \mathrm{m}$ tall, some tendency to irregular storeying of rays ("rays in echelon") observed (Fig. 1B). Disjunctive ray parenchyma cell walls present.

Crystals and silica bodies absent.

\section{Harrisonia (Fig. 2)}

The stems of Harrisonia species usually have a very wide pith. Most of the material studied is from rather juvenile branches or stems - the thickness of the xylem cylinder (from pith to cambium) is indicated for each specimen studied. 

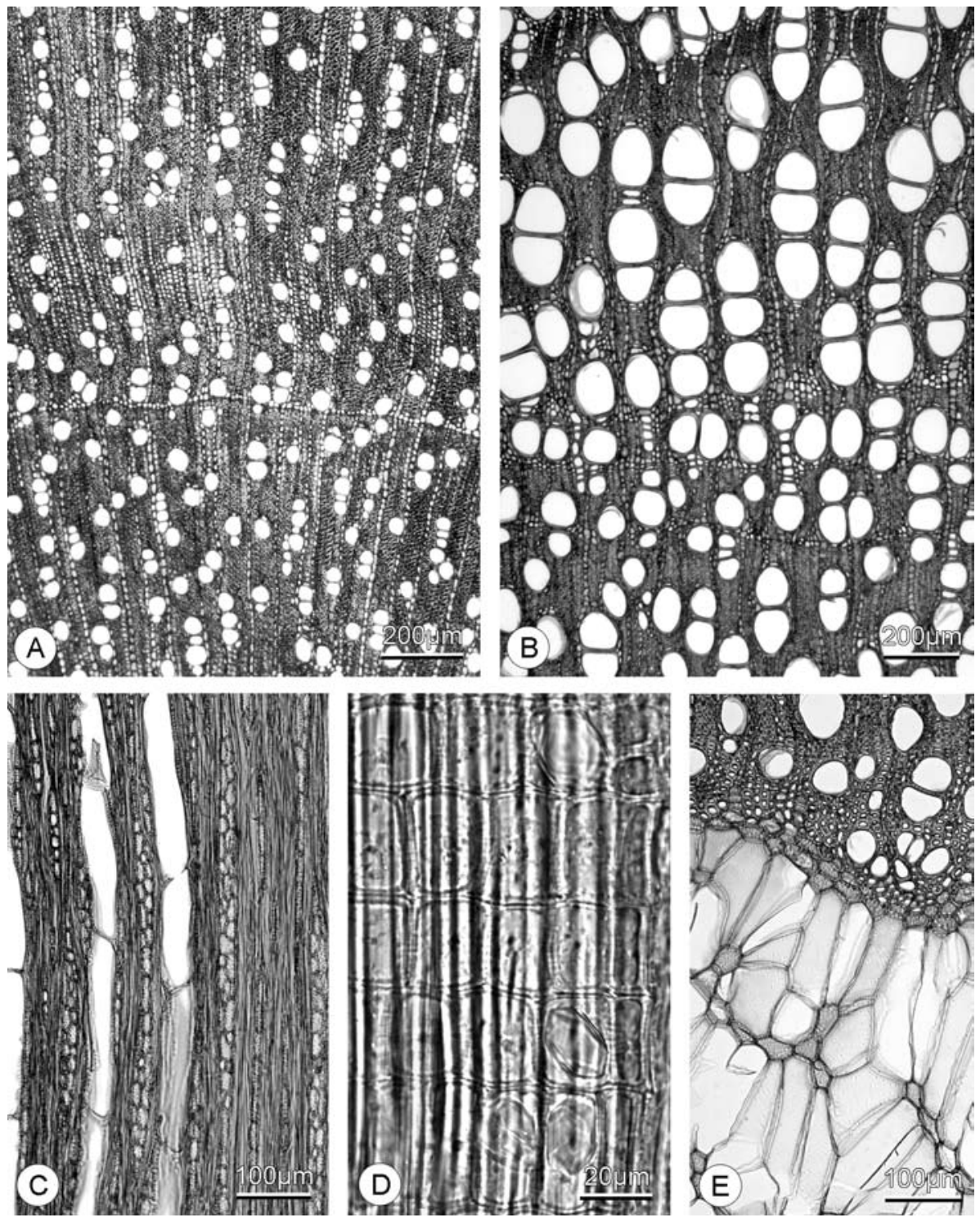

Figure 2. Wood anatomy of Harrisonia. - A: H. brownii, BHO 6415, cross section, note marginal parenchyma. - B: H. perforata, Kessler PK 1116, cross section of climber with very wide vessel elements. - C: H. perforata, J.F. Maxwell 87-902, tangential section showing uniseriate and biseriate rays. - D: H. brownii, BHO 6415, prismatic crystals in ray cells, radial section. E: H. perforata, J.F. Maxwell 87-902, cross section of heterogeneous pith composed of thinwalled inflated cells radiating from clusters of more thick-walled small cells. 
Material studied: H. abyssinica: Netherlands, Hortus botanicus Leiden (2008-1110). Appelhans MA313 (very young stem, secondary xylem $1.5 \mathrm{~mm}$ ); H. brownii: Andaman Islands, BHO 6415 = Bhargawa \& Nooteboom et al. (young stem, secondary xylem $3.5 \mathrm{~mm}$ ); H. perforata: SE Asia, sine nomine 64040 (synonym: H. paucijuga; young stem, secondary xylem $2.5 \mathrm{~mm}$ ), Thailand, J.F. Maxwell 87-902 (young stem, secondary xylem $2.5 \mathrm{~mm}$ ), Indonesia, East Kalimantan, Kessler et al. PK 1116 (climber, xylem $3.2 \mathrm{~mm}$ ).

The quantitative values below exclude the very juvenile $H$. abyssinica stem, which has narrower and more numerous vessels, and shorter vessel elements and fibres.

Growth ring boundaries fairly distinct, marked by marginal (initial) parenchyma and some differences in fibre wall thickness. Vessels diffuse, solitary and in radial multiples of 2-4(-10), multiples of $>4$ usually rare, but vessels in very young stem of $H$. abyssinica predominantly in long radial multiples and in a radial to diagonal pattern, $45-95 / \mathrm{mm}^{2}$, round to oval, tangential diameter 44-121 (8-164) $\mu \mathrm{m}$, very narrow vessels occasionally present in radial multiples, on average $21-44 \mu \mathrm{m}$ in tangential diameter, vessel element length 415-480 (280-690) $\mu \mathrm{m}$. Perforations simple. Intervessel pits alternate and small, 5-7 $\mu \mathrm{m}$ in horizontal diameter. Vessel-ray and vessel-parenchyma pits similar. Gums and tyloses absent from the vessels.

Fibres medium to very thick-walled, 706-978 (462-1241) $\mu \mathrm{m}$ long, nonseptate, with simple to minutely bordered pits mainly confined to the radial walls.

Parenchyma scanty paratracheal and marginal (initial) in bands of 1-2(-3) cells thick, parenchyma strands 3-5(-7)-celled.

Rays exclusively uniseriate (H. brownii) or with 2(-3)-seriate rays in addition, 9-17 (7-20)/mm, chiefly composed of square and upright ray cells, in thicker branches of $H$. perforata also containing some weakly procumbent cells. Ray height up to 25-65 cells $(860-1400 \mu \mathrm{m})$.

Prismatic crystals common in square and upright ray cells. One chambered crystalliferous fibre noted in H. perforata (sn 64040).

Notes: 1 . The specimen of $H$. brownii differs from those of $H$. perforata in its narrower and more numerous vessels.

2. The pith of $H$. brownii and $H$. perforata is very heterogeneous and composed of thin-walled inflated cells radiating from clusters or networks of more thick-walled cells (Fig. 2E). In the juvenile specimen of $H$. abyssinica the pith is more homogeneous. It would be interesting to study the pith anatomy of all Spathelioideae for potentially diagnostic and phylogenetically informative differences.

\section{Sohnreyia (Fig. 3)}

Material studied: S. excelsa K.Krause, Brazil, Uw 9962 (= SJRw 20689 [ herb. Ducke?], mature specimen); S. ulei (Engl. ex Harms) Appelhans \& Kessler (synonyms: Spathelia neblinaensis, Spathelia ulei), Venezuela, Uw 9961 (= Maguire et al.42315, c. mature stem).

Growth ring boundaries distinct, marked by marginal parenchyma and differences in fibre wall thickness. Vessels diffuse, in radial or radial to diagonal pattern, some solitary but mostly in long radial multiples of $2-12$, multiples of 4 or more common, 

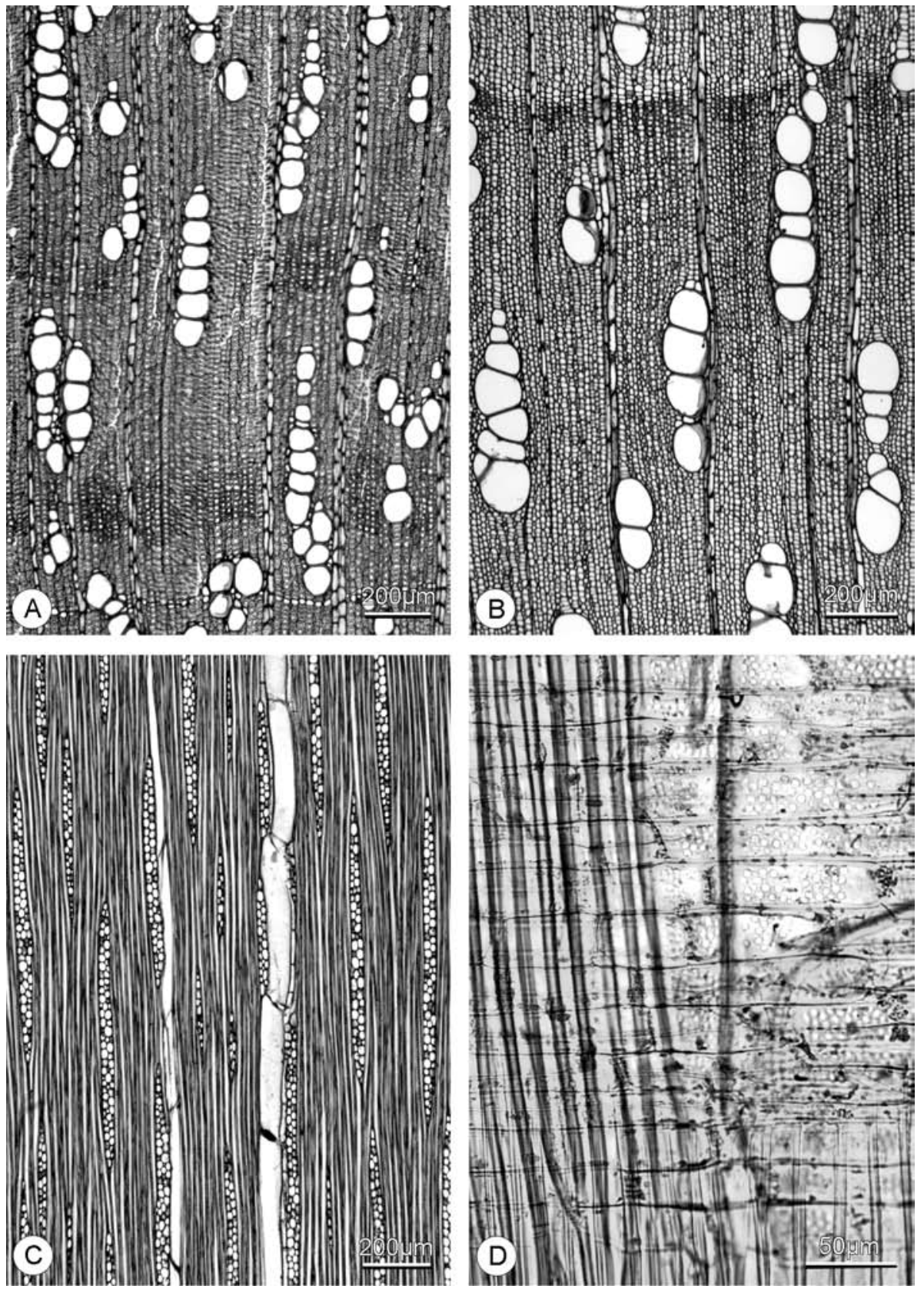

Figure 3. Wood anatomy of Sohnreyia. - A: S. ulei, Uw 9961, cross section, radial multiples of more than 4 common. - B-D: S. excelsa, Uw 9962; B: cross section; C: Tangential section showing mostly biseriate rays; D: Procumbent ray cells in radial section. 
$21-50 / \mathrm{mm}^{2}$, solitary vessels round to oval, weakly angular in $S$. ulei, tangential diameter 67-112 (45-153) $\mu \mathrm{m}$, vessel elements 499-560 (350-630) $\mu \mathrm{m}$ long. Perforations simple. Intervessel pits alternate, small , 4-6 $\mu \mathrm{m}$ in horizontal diameter. Vessel-ray and vessel-parenchyma pits similar. Gums and tyloses absent.

Fibres medium thick-walled, 890-1100 (660-1360) $\mu \mathrm{m}$ long (longest in $S$. excelsa), nonseptate, with simple to minutely bordered pits mainly confined to the radial walls.

Parenchyma scanty paratracheal and in 1-3-seriate marginal (initial) bands. Strands 3-8-celled.

Rays 1-3-seriate in S. excelsa, 1-2-seriate in S. ulei, 5-6 (4-8)/mm, exclusively homocellular and composed of procumbent cells only, or with one row of square to upright marginal cells. Ray height up to $26-58$ cells or $750-1300 \mu \mathrm{m}$ (the taller rays in S. excelsa).

Crystals absent (one empty 'ghost' seen in ray cell of S. ulei).

Note: This description is in agreement with Détienne \& Jacquet (1983), who described Sohnreyia excelsa under the name Spathelia excelsa.

\section{Spathelia (Fig. 4)}

Material studied: S. sorbifolia, Jamaica, Appelhans MA452. Flowering stem of unbranched, $6 \mathrm{~m}$ high treelet, xylem about $5 \mathrm{~mm}$ thick around a wide pith.

Growth rings indistinct to distinct, marked by differences in fibre wall thickness and very scanty marginal parenchyma. Vessels diffuse and in a radial to diagonal pattern, some solitary, but most in radial multiples of 2-10 (multiples $>4$ very common), c. $60 / \mathrm{mm}^{2}$, round to oval, tangential diameter 69 (48-103) $\mu \mathrm{m}$, vessel elements 397 (302-531) $\mu \mathrm{m}$ long. Perforations simple. Intervessel pits alternate, small, 5-6 $\mu \mathrm{m}$ in horizontal diameter. Vessel-ray and vessel-parenchyma pits similar. Gums and tyloses absent.

Fibres medium thick-walled, 577 (434-736) $\mu \mathrm{m}$ long, nonseptate, with simple to minutely bordered pits mainly confined to the radial walls.

Parenchyma extremely rare, as isolated marginal or even more rarely scanty paratracheal strands of $2-4$ cells.

Rays 1-4(-5)-seriate (broader medullary rays present near the pith), 11/mm, mostly homocellular and exclusively composed of procumbent cells, or with one row of square marginal cells. Ray height up to c. 40 cells $(1000 \mu \mathrm{m})$. Perforated ray cells infrequently present.

Crystals absent.

Note: The pith in Spathelia is composed of isodiametric parenchyma cells with thin, lignified walls.

\section{Cneorum (Fig. 5A, B)}

Wood anatomical accounts of Cneorum can be found in Carlquist (1988), Schweingruber (1990), InsideWood (2004-onwards), and Appelhans et al. (2010). A brief summary of our current anatomical understanding is presented here (see also Table 1). 

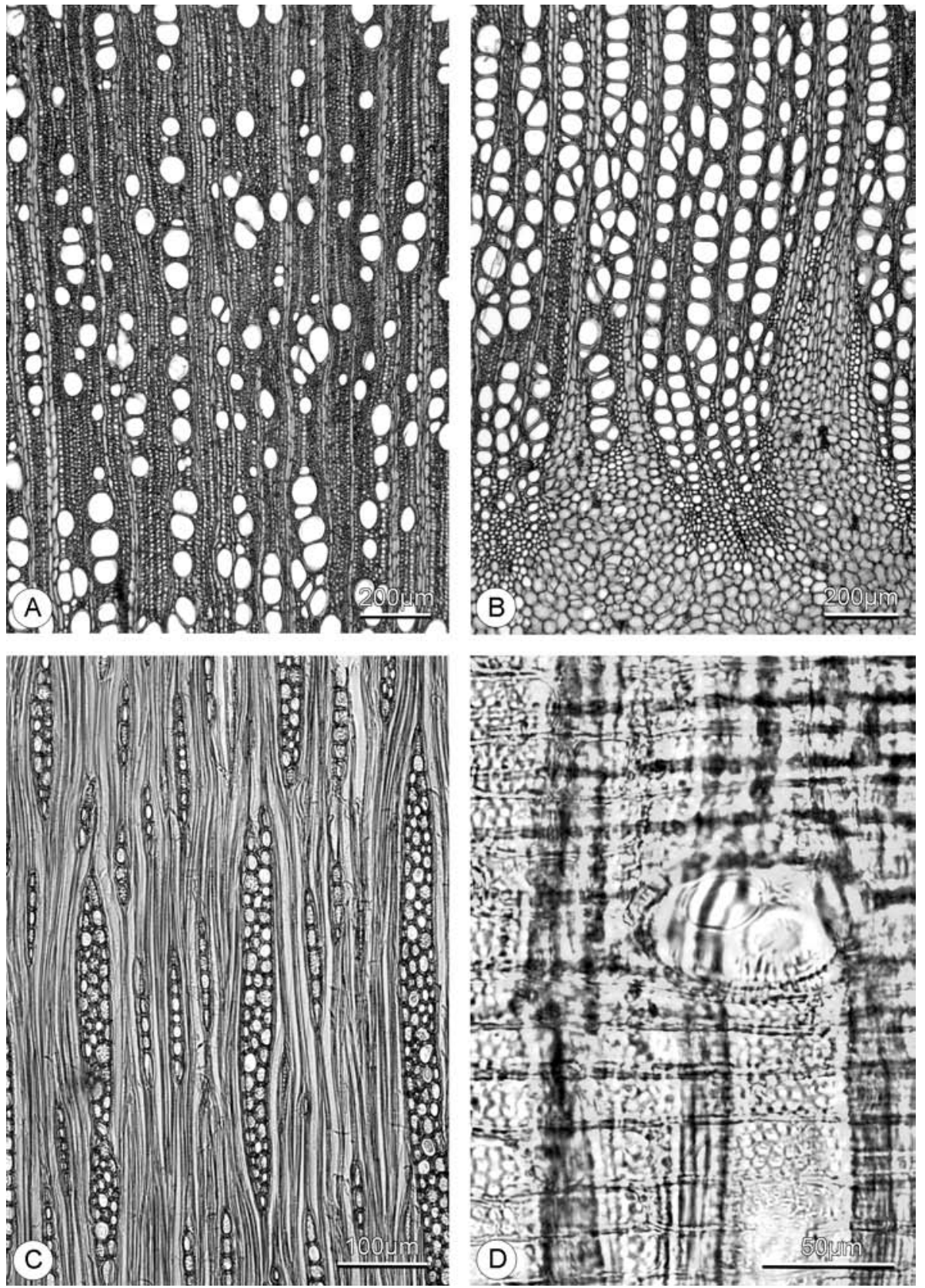

Figure 4. Wood anatomy of Spathelia sorbifolia (Appelhans MA452). - A: Cross section. B: Cross section near the pith showing very broad base of rays. - C. Tangential section showing 1-4-seriate rays. - D: Perforated ray cell in radial section. 

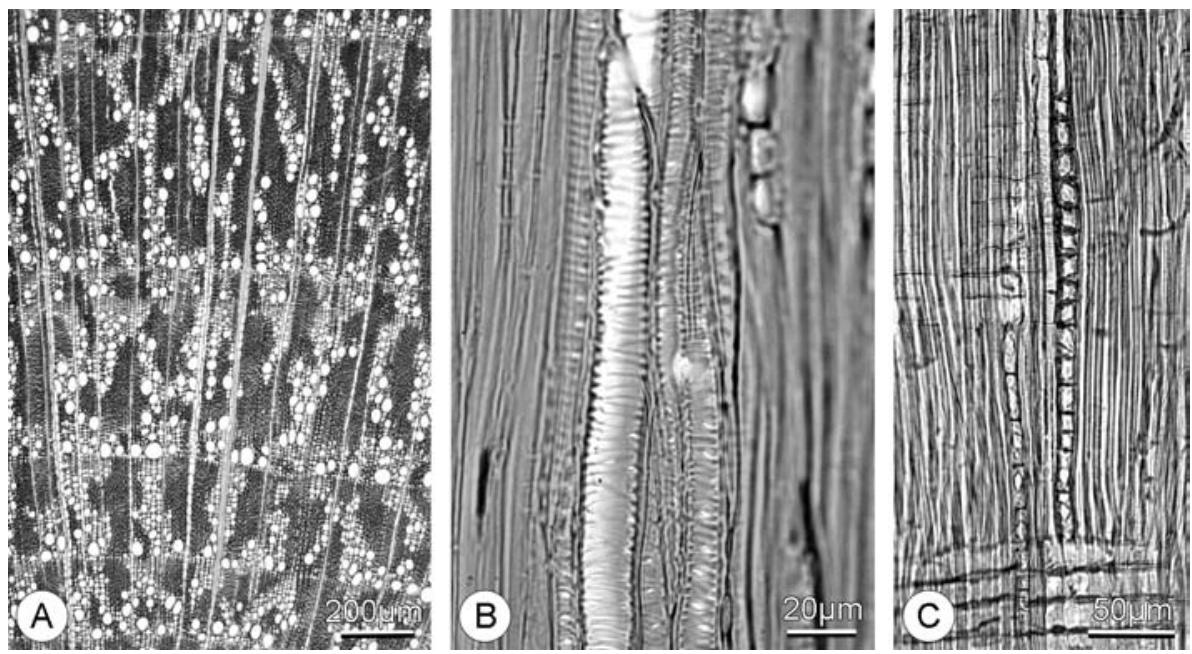

Figure 5. Wood anatomy of Cneorum tricoccon (Schweingruber s.n.) and Ptaeroxylon obliquum (FHOw 9506). - A \& B: Cneorum tricoccon; A. Cross section showing dendritic vessel pattern; B: Tangential section showing helical vessel wall thickenings. - C. Ptaeroxylon obliquum, chambered crystals in fibres, radial section.

Appelhans et al. (2010) have clarified the confusion surrounding the entity long known as $C$. trimerum, which proves to have been based on specimens of $C$.tricoccon cultivated in Cuba. Twig wood from the type specimen of $C$. trimerum strongly resembles that of $C$. tricoccon. Reduction of $C$. trimerum to synonymy under $C$. tricoccon is further supported by molecular phylogenetics (based on the type specimen of " $C$. trimerum"), pollen morphology, and macromorphology (Lobreau-Callen \& Jérémie 1986; Oviedo et al. 2009; Appelhans et al. 2010). Wood anatomical accounts by Heimsch (1942) and Carlquist (1988) of C. trimerum are most likely based on a mislabelled wood specimen of Schoepfia (Olacaceae s.l.) (Appelhans et al., 2010).

Cneorum tricoccon as described by Carlquist (1988) and Schweingruber (1990) has semi-ring porous wood, with vessels in extensive diagonal to dendritic aggregations, where 'normal' vessels are clustered with very narrow vessels intergrading with vascular (vasicentric) tracheids. Vessel and tracheid walls have distinct helical thickenings. Rays vary from exclusively uniseriate (in a twig of the type specimen of " $C$. trimerum"), to 1-3(-4)-seriate in more mature specimens, and are composed of procumbent body cells with 1-2 rows of square to upright marginal cells. Prismatic crystals are present in chambered axial parenchyma and fibres as well as in ray cells, or absent (twig of "C. trimerum" type).

Cneorum pulverulentum (Carlquist 1988) has diffuse porous wood, vessels in short to long radial multiples constituting a clear radial pattern. Faint helical sculpturing in vessels is caused by grooves interconnecting pit apertures. Vascular (vasicentric) tracheids are rare. Rays 1(-2)-seriate, but almost exclusively uniseriate, homocellular and entirely composed of procumbent cells, or weakly heterocellular with one row of square marginal cells. Crystals chambered in diffuse axial parenchyma strands. 


\section{DISCUSSION}

From Table 1 an interesting wood anatomical diversity emerges for Spathelioideae. Before discussing that diversity in a phylogenetic and ecologically adaptive context it should be stressed that our results are based on very limited sampling: although we cover all eight genera of Spathelioideae, species coverage is much lower, and of most species studied we only had one sample - often of more or less juvenile stems or branches. A much wider sampling, calling for additional field collecting in many remote localities, would doubtlessly show wider variation, especially within the genera with over three species such as Spathelia, Sohnreyia, and Cedrelopsis. More even-aged, older material would also yield differences in vessel diameter and frequency, vessel element and fibre lengths, and perhaps also in frequency, width, height and cellular composition of the rays. Despite these limitations there is a striking pattern that is probably significant and resistant to the limitations of our sampling. Figure 6 shows this pattern plotted on the most robust and recent molecular phylogeny (Appelhans et al. 2011).

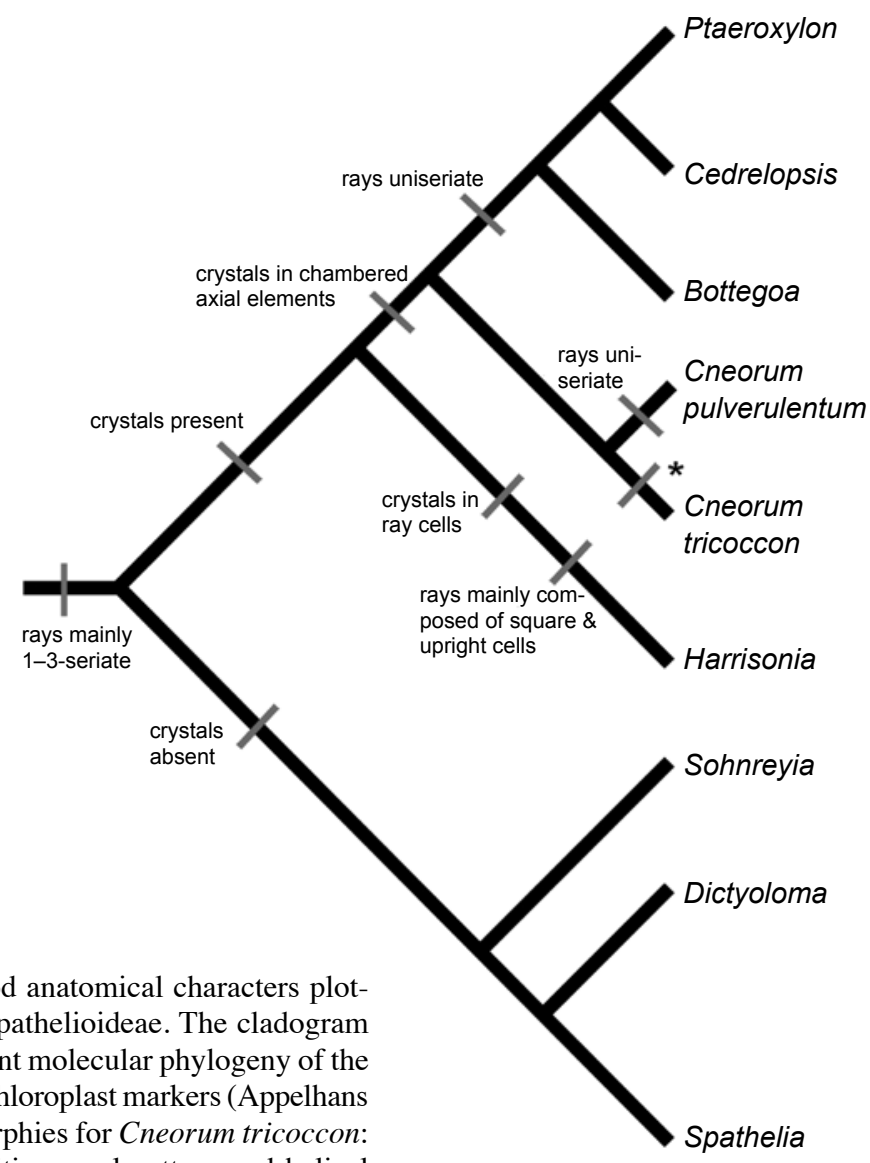

Figure 6. Important wood anatomical characters plotted on a cladogram of Spathelioideae. The cladogram is based on the most recent molecular phylogeny of the subfamily based on five chloroplast markers (Appelhans et al.2011). *Autapomorphies for Cneorum tricoccon: Rays 1-4-seriate, dendritic vessel pattern and helical thickenings, crystals in ray cells. 


\section{Vessel distribution, grouping, and helical sculpturing}

All Spathelioideae share a high degree of vessel grouping - vessel multiples of 4 or more are common throughout the subfamily. Cneorum tricoccon stands out with a distinct oblique to dendritic vessel pattern (Fig. 5A) where the narrow vessels intergrade with vascular tracheids (in vasicentric position and occurring throughout the growth ring); C. pulverulentum lacks this dendritic pattern, but has vessels in a distinct radial pattern instead (Carlquist 1988) - a pattern that is fairly common in Spathelioideae (Table 1). Cneorum tricoccon is also unique in showing distinct helical thickenings on the vessel walls and vascular tracheids (Fig. 5B); C. pulverulentum is on record to have some helical sculpturing in the form of grooves associated with the intervessel pit apertures (Carlquist 1988).

\section{Ray width and ray cellular composition}

Rays are almost exclusively uniseriate in the African and Malagasy genera Bottegoa, Cedrelopsis, and Ptaeroxylon, 1-3-seriate in the New World genera Dictyoloma, Sohnreyia and Spathelia and variable in Cneorum and Harrisonia. Cneorum tricoccon and Harrisonia perforata even vary in ray width below the species level, with the type specimen of $C$. trimerum (now $C$. tricoccon) having exclusively uniseriate rays in its juvenile xylem (Appelhans et al.2010) and the other specimens from Mallorca and garden cultivation in California having 1-3(-4)-seriate rays (Carlquist 1988; Schweingruber 1990).

Ray composition also varies: in most genera rays are homocellular or very weakly heterocellular with procumbent cells flanked by a single row of square to weakly upright cells. In the New World clade this pattern is already evident very close to the pith (despite the general tendency that in early ontogeny rays often start with a high percentage of upright cells). Rays in Harrisonia are mainly composed of square and upright cells, while in the very juvenile material of Bottegoa, documented by Van der Ham et al. (1995) and Cneorum there is a transition from rays composed of upright and square cells near the pith, to increasing proportions of procumbent cells near the bark in older stems (new observations).

\section{Crystals}

Crystals are absent from the New World Spathelioideae studied by us. In the Old World clade there is an interesting pattern: Harrisonia has prismatic crystals common in ray cells, the African and Malagasy subclade of Bottegoa, Cedrelopsis and Ptaeroxylon (Fig. 5C) has chambered crystals in diffuse axial parenchyma and fibres, while Cneorum is again variable: the type specimen of $C$.trimerum - now C.tricoccon (very juvenile wood) - is devoid of crystals, and the other specimens of $C$. tricoccon show both prismatic crystals in ray cells and in chambered axial parenchyma cells, and C.pulverulentum has chambered crystals only (cf. Carlquist 1988; Schweingruber 1990).

\section{Characters common to Spathelioideae and other Rutaceae}

Most Spathelioideae share diffuse porous wood (only Cneorum tricoccon is semi-ring porous) with faint to distinct growth ring boundaries marked by marginal parenchyma 
and/or differences in fibre wall thickness. Long radial vessel multiples are common. Vessels have simple perforations, small, alternate intervessel pits and similar vesselray and vessel-parenchyma pits. Fibres are medium- to very thick-walled, nonseptate, and have simple to minutely bordered pits mainly confined to the radial walls. Axial parenchyma is scanty paratracheal (extremely scanty or nearly absent in Spathelia) and occurs in varying distinctiveness as often discontinuous, marginal (initial) bands. Rays are always narrow: 3-seriate or narrower, with one exception in a Cneorum specimen from Mallorca that has up to 4-seriate rays (cf. Schweingruber 1990).

This suite of anatomical characters is extremely common in Rutaceae as a whole (Metcalfe \& Chalk 1950; Ilic 1991; InsideWood 2004-onwards) and one cannot pinpoint a wood anatomical character, which is unique to Spathelioideae. Differentiating features for Spathelioideae such as chambered crystals in axial parenchyma and fibres and crystals in ray cells, rays exclusively uniseriate or 1-3-seriate also are widespread in Rutaceae (Metcalfe \& Chalk 1950; Klaassen 1999).

\section{Phylogenetic signals within Spathelioideae}

Figure 6 clearly shows that the wood anatomical diversity within Spathelioideae, despite the fact that this diversity is restricted to a limited number of characters, offers strong support for various nodes in the phylogeny reconstruction based on sequence data of five chloroplast markers (Appelhans et al. 2011): The Old World clade is supported by prismatic crystals - either in the rays, or in chambered parenchyma and fibres or both. The African and Malagasy subclade is supported by exclusively uniseriate rays and chambered crystals. Harrisonia is supported by crystals in ray cells and rays mainly composed of square and upright cells. Cneorum does not share a single synapomorphy - instead $C$. tricoccon has marked autapomorphies in its vessel pattern and helical thickenings on its vessel and tracheid walls. Cneorum pulverulentum shares most synapomorpies of the African-Malagasy clade. In crystal complement C. tricoccon bridges the gap between Harrisonia and the African-Malagasy genera. The New World clade (Dictyoloma-Sohnreyia-Spathelia) is supported by rays composed of procumbent cells from early ontogeny onwards.

The striking congruence of the wood anatomical diversity pattern with multiple nodes in the independently reconstructed molecular phylogeny of Spathelioideae (Appelhans et al.2011) supports the notion that wood anatomy does preserve strong phylogenetic signals at many levels of the taxonomic hierarchy (cf. Baas et al. 2000; Lens et al. 2007).

\section{Ecological signals in Spathelioideae: vessel patterns in Cneorum tricoccon}

Multiple studies have demonstrated strong correlations between ecology and wood anatomy within woody clades or entire floras (for summaries see Carlquist 2001; Baas et al. 2004; Wheeler et al.2007; Baas \& Wheeler 2011). Features such as vessel diameter, vessel frequency, and vessel grouping affect the hydraulic efficiency and safety of a tree and shrub in its habitat, in interaction with temperature, drought, and seasonality (Carlquist 1984; Hacke \& Sperry 2001; Hacke et al. 2006; Lens et al. 2011). The ecology of most Spathelioideae is only rather sketchily known (Appelhans et al. 2011, 2012); almost all grow in dry to mesic vegetation in the tropics. The only 
exception is Cneorum of which C.tricoccon is chiefly Mediterranean, occurring from Southern Italy towards the Western Mediterranean, while $C$. pulverulentum grows in the dry parts of the subtropical Canary Islands. Cneorum tricoccon is the only species in Spathelioideae that has the syndrome of oblique to dendritic vessel patterns, vascular tracheids and helical thickenings on the vessel and tracheid walls, a combination of features that occurs elsewhere in Rutaceae in phylogenetically unrelated genera: Acradenia Kippist (Australia and Tasmania), Cneoridium Hook.f. (Southern California and Northern Mexico), Leionema (New Zealand; listed as Phebalium nudum in Heenan \& Moar 1997), Nematolepis (Australia; listed as Phebalium squameum in Ilic 1991), Orixa Thunb. (China, Japan, Korea) and Skimmia Thunb. (China and Japan but here helical thickenings are absent). Carlquist $(1987,2001)$ hypothesized that this syndrome is highly adaptive for hydraulic safety in either Mediterranean or cold temperate or montane environments. Baas and Schweingruber (1987) and Baas (in Schweingruber 1990) in an analysis of ecological trends in European trees and shrubs, suggested that hydraulic safety was provided by vascular tracheids and intergrading very narrow vessels, while conductive efficiency was served by 'normal' vessels in woods that show two or more vessel diameter classes in their secondary xylem. Woods with dendritic vessel patterns typically show this dual strategy, especially if it is associated with semi-ring porosity as in Cneorum tricoccon. Dendritic/diagonal vessel patterns associated with vascular tracheids, and very often also with helical vessel and tracheid wall thickenings are very common in the Mediterranean flora: $33 \%$ of all 301 Mediterranean species documented by Schweingruber (1990) show this syndrome, while in higher latitudes in Europe it is not more than 5\% (new statistics based on Schweingruber's Atlas); in the Mediterranean regions of California and Israel there is also a very high proportion of species showing the syndrome (Carlquist \& Hoekman 1985; Baas \& Carlquist 1985).

Based on the polyphyletic nature of the dendritic vessel pattern syndrome in Rutaceae, and the distinct ecological trends for this feature in both Rutaceae and woody floras as a whole (see also Wheeler et al . 2007), it is obvious that the - for Spathelioideae unique wood anatomy of Cneorum tricoccon can be interpreted as a functional adaptation of its hydraulic system to the seasonally changing demands for conductive efficiency and safety in the Mediterranean climate. Interestingly the subtropical Canary Island species $C$. pulverulentum lacks this adaptation. This lack might be explained by the less-seasonal climate of the Canary Islands as compared to the Mediterranean (Juan et al. 2000). We hypothesize that Cneorum has a tropical African ancestor (see also ancestral area reconstruction in Appelhans et al. 2012) and lacked dendritic vessel patterns, and that $C$. tricoccon evolved its Mediterranean xylem adaptations upon arrival in Europe after the split from $C$. pulverulentum.

For a reliable reading of other ecological signals in the wood of Spathelioideae our sampling is too limited and contains too many juvenile samples. The great range of variation in vessel frequency and vessel diameter in Spathelioideae must be partly due to different ages of the samples, but the highest values for vessel diameter in one highly juvenile specimen (Kessler 1116) of Harrisonia perforata (Fig 2B) is due to its climbing habit. 


\section{CONCLUDING REMARK}

Spathelioideae show an interesting wood anatomical pattern of diversity, that supports earlier phylogenetic hypotheses based on DNA analyses, and - in the case of Cneorum also bears witness of functional adaptation to a climatic regime, outside the main tropical distribution area of the subfamily. As so often in comparative wood anatomy, the adaptive wood anatomical syndrome of Cneorum tricoccon is highly diagnostic at the same time.

\section{ACKNOWLEDGEMENTS}

We would like to thank Patrick Lewis (UCWI) for his help during a collecting trip to Jamaica by the first author as well as the Leiden University Fund (LUF; 9103/27-1-09/N) and the Alberta Mennega Stichting for supporting this fieldwork. Two reviewers of the IAWA Journal gave very useful suggestions for improvement of the manuscript.

\section{REFERENCES}

Appelhans, M.S., P.J.A. Keßler, E. Smets, S.G. Razafimandimbison \& S.B. Janssens. 2012. Age and historical biogeography of the pantropically distributed Spathelioideae (Rutaceae, Sapindales). J. Biogeo. 39: 1235-1250.

Appelhans, M.S., E. Smets, P. Baas \& P.J.A. Keßler. 2010. Cneorum (Rutaceae) in Cuba? The solution to a 150 year old mystery. Taxon 59: 1126-1134.

Appelhans, M.S., E. Smets, S.G. Razafimandimbison, T. Haevermans, E.J. van Marle, A. Couloux, H. Rabarison, M. Randrianarivelojosia \& P.J.A. Keßler. 2011. Phylogeny, evolutionary trends, and classification of the Spathelia/Ptaeroxylon clade: morphological and molecular insights. Ann. Bot. 107: 1259-1277.

Baas, P. \& S. Carlquist. 1985. A comparison of the ecological wood anatomy of the floras of southern California and Israel. IAWA Bull. n.s. 6: 349-353.

Baas, P., P.M. Esser, M.E.T. van der Westen \& M. Zandee. 1988. Wood anatomy of the Oleaceae. IAWA Bull. n.s. 9: 103-182.

Baas, P., F.W. Ewers, S.D. Davies \& E.A. Wheeler. 2004. The evolution of xylem physiology. In: A.R. Hemsely \& I. Poole (eds.), Evolution of plant physiology from whole plants to ecosystems: 273-296. Elsevier Academic Press, London.

Baas, P. \& F.H. Schweingruber. 1987. Ecological trends in the wood anatomy of trees, shrubs and climbers from Europe. IAWA Bull. n.s. 8: 245-274.

Baas, P. \& E.A. Wheeler. 2011. Wood anatomy and climate change. In: T.R. Hodkinson, M.B. Jones, S. Waldren \& J.A.N. Parnell (eds.), Climate change, ecology and systematics: 141-155. Cambridge University Press, Cambridge.

Baas, P., E.A. Wheeler \& M. Chase. 2000. Dicotyledonous wood anatomy and the APG system of angiosperm classification. Bot. J. Linn. Soc. 134: 3-17.

Bentham, G. \& J.D. Hooker. 1862. Genera Plantarum, vol. 1. Reeve, London.

Bramwell, D. \& Z.I. Bramwell. 1990. Flores sylvestres de las Islas Canarias. Editorial Rueda S.L., Madrid.

Carlquist, S. 1984. Vessel grouping in dicotyledon wood: significance and relationship to imperforate tracheary elements. Aliso 10: 505-525.

Carlquist, S. 1987. Diagonal and tangential vessel; aggregations in wood: function and relation to vasicentric tracheids. Aliso 11: 451-462.

Carlquist, S. 1988. Wood anatomy of the Cneoraceae: ecology, relationships and generic definition. Aliso 12: 7-17. 
Carlquist, S. 2001. Comparative wood anatomy. Ed. 2. Springer, Berlin, Heidelberg.

Carlquist, S. \& D.A. Hoekman. 1985. Ecological wood anatomy of the woody southern Californian flora. IAWA Bull. n.s. 6: 319-347.

Chase, M.W., C.M. Morton \& J.A. Kallunki. 1999. Phylogenetic relationships of Rutaceae: a cladistic analysis of the subfamilies using evidence from rbcL and atpB sequence variation. Amer. J. Bot. 86: 1191-1199.

Chiovenda, E. 1916. Resultati scientifici della missione Stefanini-Paoli nella Somalia italiana. 1. Le collezioni botaniche. Florence.

Détienne, P. \& P. Jacquet. 1983. Atlas d'identification des bois de l'Amazonie et des regions voisines. Centre Tech. For. Trop., Nogent-sur-Marne.

Engler, A. 1931. Rutaceae. In: A. Engler \& H. Harms (eds.), Die natürlichen Pflanzenfamilien. Band 19a: 187-359. Wilhelm Engelmann, Leipzig.

Groppo, M., J.R. Pirani, M.L.F. Salatino, S.R. Blanco \& J.A. Kallunki. 2008. Phylogeny of Rutaceae based on two noncoding regions from cpDNA. Amer. J. Bot. 95: 985-1005.

Hacke, U.W. \& J.S. Sperry. 2001. Functional and ecological xylem anatomy. Perspectives in plant ecology. Evolution \& Systematics 4: 97-115.

Hacke, U.W., J.S. Sperry, J.K. Wheeler \& L. Castro. 2006. Scaling of angiosperm xylem structure with safety and efficiency. Tree Physiology 26: 689-701.

Heenan, P.B. \& N.T. Moar. 1997. Wood anatomy of the dicotyledons indigenous to New Zealand 26: Rutaceae. N.Z. J. Bot. 35: 229-242.

Heimsch, C. 1942. Comparative anatomy of the secondary xylem in the Gruinales and Terebinthales of Wettstein with reference to taxonomic grouping. Lilloa 8: 83-197.

Ilic, J. 1991. CSIRO Atlas of hardwoods. CSIRO, Australia.

InsideWood. 2004-onwards. Published on the Internet: http://insidewood.lib.ncsu.edu/search

Juan, C., B.C. Emerson, P. Oromí \& G.M. Hewitt. 2000. Colonization and diversification: towards a phylogeographic synthesis for the Canary Islands. Trends Ecol. Evol. 15: 104-109.

Klaassen, R.K.W.M.1999. Wood anatomy of the Sapindaceae. IAWA J., Supplement 2. 214 pp.

Kubitzki, K., J.A. Kallunki, M. Duretto \& P.G. Wilson. 2011. Rutaceae. In: K. Kubitzki (ed.), The families and genera of vascular plants. Vol. 10: 276-356. Springer Verlag, Berlin.

Lens, F., J. Schönenberger, P. Baas, S. Jansen \& E. Smets. 2007. The role of wood anatomy in phylogeny reconstruction of Ericales. Cladistics 23: 229-254.

Lens, F., J.S. Sperry, M.A. Christman, B. Choat, D. Rabaey \& S. Jansen. 2011. Testing hypothesis that link wood anatomy to cavitation resistance and hydraulic conductivity in the genus Acer. New Phytol. 190: 709-723.

Leroy, J.F. 1959. Contributions à l'étude des forêts de Madagascar. V. Sur une petite famille de Sapindales propre à l'Afrique australe et à Madagascar: les Ptaeroxylaceae. J. Agric. Trop. Bot. Appl. 6: 106-108.

Leroy, J.F. 1960. Contributions à l'étude des forêts de Madagascar. Complément à la note V sur les Ptaeroxylaceae. J. Agric. Trop. Bot. Appl. 7: 455-456.

Lobreau-Callen, D. \& J. Jérémie. 1986. L'espèce Cneorum tricoccon (Cneoraceae, Rutales) représentée à Cuba. Grana 25: 155-158.

Metcalfe, C.R. \& L. Chalk. 1950. Anatomy of the Dicotyledons. Clarendon Press, Oxford.

Mollel, N.P., P. Détienne \& E.A. Wheeler. 2008. Anatomy of Cedrelopsis. In: D. Loupe, A.A. Oteng-Amoaka \& M. Brink (eds), Plant Resources of Tropical Africa 7 (1). Timbers 1: 144. PROTA Foundation, Wageningen.

Nooteboom, H.P. 1962. Simaroubaceae. In: C.G.G.J. Van Steenis (ed.), Flora Malesiana ser. 1 vol. 6: 193-226. Wolters-Noordhoff Publishing, Groningen.

Oviedo, R., A. Traveset, A. Valido \& G. Brull. 2009. Sobre la presencia de Cneorum (Cneoraceae) en Cuba: ejemplo de disyunción biogeographical Mediterráneo-Caribe? Anales Jard. Bot. Madrid 66: 25-33. 
Planchon, J.E. 1846. Revue de la famille des Simarubacées. London J. Bot. 5: 560-584.

Razafimandimbison, S.G., M.S. Appelhans, H. Rabarison, T. Haevermans, A. Rakotondrafara, S.R. Rakotonandrasana, M. Ratsimbason, J.N. Labat, P.J.A. Keßler, E. Smets, C. Cruaud, A. Couloux \& M. Randrianarivelojosia. 2010. Implications of a molecular phylogenetic study of the Malagasy genus Cedrelopsis and its relatives (Ptaeroxylaceae). Mol. Phylogenet. Evol. 57: 258-265.

Schweingruber, F.H. 1990. Anatomy of European woods. Haupt, Bern.

Straka, H., F. Albers \& A. Mondon. 1976. Die Stellung und Gliederung der Familie Cneoraceae (Rutales). Beitr. Biol. Pflanz. 52: 367-310.

Takhtajan, A. 1997. Diversity and classification of flowering plants. Columbia University Press, New York.

Thorne, R.F. 1992. An updated phylogenetic classification of the flowering plants. Aliso 13: 365-389.

Traveset, A. 1995. Seed dispersal of Cneorum tricoccon L. (Cneoraceae) by lizards and mammals in the Balearic Islands. Acta Oecologia 16: 171-178.

Van der Ham, R.W.J.M., P. Baas, M.E. Bakker, F.D. Boesewinkel, F. Bouman, B.J. van Heuven \& R.K.W.M. Klaassen. 1995. Bottegoa Chiov. transferred to the Ptaeroxylaceae. Kew Bull. 50: 243-265.

Wheeler, E.A. 2011. InsideWood - a web resource for hardwood anatomy. IAWA J. 32: 199-211.

Wheeler, E.A., P. Baas \& P.E. Gasson (eds). 1989. IAWA List of microscopic features for hardwood identification. IAWA Bull. n.s. 10: 219-332.

Wheeler, E.A., P. Baas \& S.A. Rodgers. 2007. Variations in dicot wood anatomy: a global analysis based on the InsideWood database. IAWA J. 28: 229-258.

White, F. 1986.The taxonomy, chorology and reproductive biology of southern African Meliaceae and Ptaeroxylaceae. Bothalia 16: 143-168. 